University of Michigan Law School

University of Michigan Law School Scholarship Repository

Articles

Faculty Scholarship

1988

\title{
Some Aspects of Householding in the Medieval Icelandic Commonwealth
}

William I. Miller

University of Michigan Law School, wimiller@umich.edu

Available at: https://repository.law.umich.edu/articles/1068

Follow this and additional works at: https://repository.law.umich.edu/articles

Part of the Comparative and Foreign Law Commons, Family Law Commons, Legal History Commons, and the Property Law and Real Estate Commons

\section{Recommended Citation}

Miller, William I. "Some Aspects of Householding in the Medieval Icelandic Commonwealth." Continuity \& Change 3 (1988): 321-55.

This Article is brought to you for free and open access by the Faculty Scholarship at University of Michigan Law School Scholarship Repository. It has been accepted for inclusion in Articles by an authorized administrator of University of Michigan Law School Scholarship Repository. For more information, please contact mlaw.repository@umich.edu. 


\title{
Some aspects of householding in the medieval Icelandic commonwealth
}

\author{
WILLIAM IAN MILLER*
}

The emergence of the nuclear family and the appearance of the simple household from the embarrassment of clan, kin, hall and longhouse in western Europe and America has been discovered now in every century from the ninth to the nineteenth. ${ }^{1}$ In a recent piece in Annales, Jenny Jochens proposes the same pattern of evolution for twelfth- and thirteenth-century Iceland. ${ }^{2}$ This is remarkable considering the author's recognition of other household arrangements and her ascertainment of an early age of marriage for both sexes, ${ }^{3}$ early, that is, relative to the levels associated with the European marriage pattern of the early modern period. ${ }^{4}$ But the sources, I believe, compel different conclusions; they have much to tell us about complex households. They do show us simple households, to be sure, but these were often on their way to entering a complex phase when wealthy, or on their way to being assimilated into wealthier households when impoverished. Complex householding, it seems, was not an unlikely phase for a significant number of households to pass through during their life cycles. But my intention is not to prove that Iceland had a joint-household system, it is rather to give a fairly elaborate account of the evidence in order to see how well orthodox household analysis fares in the Icelandic setting and to show that Iceland can in no way be characterised as a simple-household society. We shall see that the usual definitions and typologies take us only so far; that they must be loosened considerably to accommodate the fluidity of Icelandic householding and mobility of people between households; and that we must take account of the fact that the Icelandic laws talk about

* University of Michigan Law School. 
households in a way not entirely agreeable to the accepted categories. Limitations of length constrain me to exclude discussion of the relation of household structure to the wider kin network and to extra-household politics, except in a most cursory manner. The sources, however, are quite clear on the interrelatedness of household, kin, and inter-household affairs and so, in spite of the arbitrary boundaries I might wish to draw for convenience of exposition, one will sense the kin and others lurking about the margins of the page.

There has been much, mostly inconclusive, discussion about how to define the household in a manner suitable for comparative purposes. ${ }^{5}$ Certain conventional criteria are not very useful in the Icelandic context, where it appears that a person could be attached to more than one household, where the laws suggest it was possible for more than one household to be resident in the same uncompartmentalised farmhouse; and where headship might often be shared. ${ }^{6}$ Definitions, for example, based on coresidence or on commensalism ${ }^{7}$ do not jibe all that well with the pastoral transhumance practised by the Icelanders. Sheep were tended and milked in summer in high pasture at shieldings by servants and other household members who slept and ate there during the summer but who were still understood to be attached to the main lowland farm in which other household members lived the entire year. Still, both coresidence and commensalism are a big part of what an Icelandic household was about, but a certain definitional roughness and subjectivity is needed in order to accommodate native categories and conceptions. ${ }^{8}$ For the purpose of this study I consider a person's household to be where s/he eats and sleeps most of the time and where, even when not sleeping or eating there, he or she is perceived to have some right or duty to do so. This kind of looseness will cause trouble in marginal cases, but it is fairly serviceable nevertheless. It also allows for the possibility of multiple-household membership; something the ethnographic evidence suggests should not be totally precluded by definitions all too often adopted, without much refinement from the census taker, and it takes better account of the demands of the native style of pastoralism. Although qualifications and modifications will emerge when we consider the sources, I adopt for convenience the terminology of household type settled on by the Cambridge Group. ${ }^{9}$ Households are either simple or complex. A simple household has as its base the conjugal family unit, that is, a married couple and their unmarried children, but it also includes households headed by a single parent with children as well as married couples without children. Complex households, on the other hand, are said to be extended if they include other relatives who do not form conjugal units of their own. They are joint or multiple ${ }^{10}$ if they are comprised of two or more related married couples, 
although to make sense in the Icelandic context, the class of married couples must include those living in 'loose marriages', i.e. open and regularised concubinage. ${ }^{11}$ Also, native classifications of multiple householding need not depend on the kinship connection between the married couples. I thus consider, contrary to the Cambridge typology, that a farmstead run as a unified economic enterprise can constitute a single household even if some of its members are not related or do not recite kinship as the reason they are housed together. ${ }^{12}$

The medieval Icelandic sources on household and kin are problematic. ${ }^{13}$ The sources are either narrative or normative, that is, sagas or laws. ${ }^{14}$ Neither class of source material offers much direct information on household type; what data there is must be extricated from passing comments in contexts devoted explicitly to other matters. Because the contexts are invariably accounts of feud and kinstrife in the sagas, and matters of legal regulation in the laws, one might expect a bias toward the over-representation of household types that were conducive to kinstrife, like complex households. While this is something to be wary of, the sagas, for reasons to be discussed later, do not focus much attention on internal disputes in complex households. The laws, on the other hand, do evidence a special concern regarding confusions of legal process when more than one householder occupies the same farmstead. Determining the typicality of household type from this evidence is troublesome. Moreover, neither of these sources lends itself to statistical analysis. Because of the smallness of sample size and the criteria for selection of household descriptions when they do appear, attempts to acquire statistics on medieval Icelandic household types would have to founder. The sagas, for instance, tend to give relatively dense descriptions of only the wealthier households of chieftains and big farmers; they make only bare mention, with little or no description, of the impoverished households of poor farmers, tenants, and búdsetumenn (cottagers). ${ }^{15}$ Unfortunately, for the present at least, we must proceed by feel and hunch and illustrate by anecdote.

Another difficulty lies in fixing the time to which the sources apply. The sagas are products of the thirteenth century, but the family sagas from which some of our more detailed descriptions come have their setting in the Saga Age in the late tenth and early eleventh centuries. In addition to the family sagas are others, also composed in the thirteenth century, which describe events that are nearly contemporaneous with their composition or occurred no earlier than the prior century. Most of these are collected in a compilation known as Sturlunga saga. ${ }^{16}$ The differences in matters of social and legal description between the family sagas and Sturlunga saga are not as great as their similarities and although the family sagas pose problems as historical sources, these problems are neither insurmountable, 
nor any less vexatious than those posed by Sturlunga saga. And, especially because casual descriptions of household type were rarely essential to the plot, they were not very likely to suffer deformity from the fictionalising process. ${ }^{17}$ Without going into tedious detail, the family sagas, when describing events subsequent to the period of colonisation and original settlement, offer a fair reflection of the range of householding patterns seen in the contemporary sagas. I thus make use of both types of saga source and consider the collection of evidence to be fairly representative of conditions in a 125 year period beginning sometime in the second half of the twelfth century.

The basic unit of residence, production, and reproduction in Iceland was the farmstead. Until the end of the eighteenth century there were no villages or towns, no nucleated settlements at all. The main crop was grass, which fed the sheep and cattle. During the summer months the sheep were pastured in the uplands where some members of the household would be assigned to shielings to care for and milk the animals. The sheep were rounded up in autumn, and brought back to the farms which dotted the river valleys below. Cereals, mainly barley, were harvested in some areas in the south and west but the short growing season was precariously close to the minimum needed for the plants to complete their life cycle. Climatic deterioration starting in the thirteenth century led to the abandonment of cereal cultivation in many places. ${ }^{18}$ Meat and dairy products from the herds were supplemented by fish and stranded whales, but in spite of the richness of the oceanic resources the social organisation of the economy centred on animal husbandry. ${ }^{19}$

\section{NATIVE TERMINOLOGY}

The philology of residence generally designated the farm and its buildings as a bær. The farm buildings were also called hús (sg. and pl.), although hu's could also indicate rooms within the farmhouse and were not necessarily detached structures (see, e.g. Grágás II 260-61). Partially congruent with the notion of brer was that of the $b \dot{u}$, deriving from the same root. ${ }^{20}$ The bu was the household; it included the livestock, the place, the enterprise and the juridical unit. When two people had a $b u$ at the same $b a r$ they were said to have a bú together (eiga bu saman). To set up a household or to start farming was to gora bú, reisa bú, but also gora boe (acc. of berr). The complex of buildings and the juridical unit was also known as a hibyli, the first element of which is related to hju, hjün, which designates the conjugal unit, husband and wife. Both of these forms - hju, hjuin - were extended in meaning to include the entire population of the 
hibyli or bu-especially the servants, and even the family, in short, the household, or in the words of the laws glossing skuldahjun: 'all those whom a householder is obliged to maintain and those workmen who need to work to that end' (Grágás Ia 159).

Complex householding arrangements were indicated by the terms tvibyli, félagsbú, builag and the phrase eiga bú saman. The sources, however, are not circumstantial enough to determine the precise arrangement indicated by each term. Modern Icelandic usage and etymological inference suggest that a tvibyli involved the separation of some economic functions. Much of the farm's management was still unified, with headship (probably) being shared, but the livestock and tools of each bóndi were separately owned and accounted for. ${ }^{21}$ It is a matter of definition whether a tvibyli should be counted as two independent households sharing the same farmhouse or as a type of complex householding arrangement. Since there is no evidence whatsoever that the members of a tvibyli did not eat together and share sleeping quarters it seems better to treat it as a complex household. A félagsbú and a búlag seem to indicate a unified economic enterprise with property held in a kind of partnership. Eiga bu saman applied to both types of arrangement. ${ }^{22}$ None of these terms fits precisely the definitions of the Cambridge group, but then nothing is to be gained by rejecting native categories in favour of imposing categories generated from other types of sources in other historical settings. The exact sense of household is bound to be strongly dependent on the culture the researcher is describing. The bu is something more than the coresidential unit, including as it does the economic enterprise. The hjún too was defined in reference to the economic enterprise. Its semantic range integrated household head and his wife with the servants and dependants who made up what was perceived as a social solidarity. The various terms for complex householding are also economically based. But given the nature of the economic enterprise a sense of household deriving from economic arrangements will necessarily indicate a coresidential and common consuming unit also.

THE HOUSEHOLD IN THE LAWS:

THE PROBLEM OF THE 'JURIDICAL HOUSEHOLD'

Icelandic legal process placed an extraordinary significance on the formal attachment of everyone to an identifiable household and on the status of the people therein as to whether they were householders (bóndi, pl.bondr), ${ }^{23}$ or servants (heimamenn, -konur griđmenn, -konur, húskarlar). ${ }^{24} \mathrm{We}$ are thus given a fair amount of information about households in the sections of the laws dealing with summoning procedure, with the calling of neighbours as witnesses and as members of jury-like panels, and with 
thing attendance (see, e.g. Grágás Ia 128-39, also ra 51-52, 63; II 320-25). One section provides that anyone who starts a household (bú) in the spring must declare himself to be 'in thing' with a chieftain (Grágás Ia 136). ${ }^{25}$ The text then defines household so as to clarify exactly who must make the declaration:

A household ( $\left.b u^{\prime}\right)$ exists when a man has milk animals and he must also declare himself in
thing if he is a landowner even if he doesn't have milk animals. If he is not a landowner or
he has no milk animals he is attached to the thing of the householder (bóndi) to whose charge
he commits himself (Grágás Ia 136.)

As a property-based definition this provision has little in common with formally-based definitions and only marginal connection to an economicfunctional definition. Still it is suggestive. The provision allows tenants, even the lowly kotkarl and büJsetumaor (cottager), to qualify as independent householders. It suggests also the possibility of several 'juridical households' ${ }^{\text {'6 }}$ existing concurrently at the same farmstead whenever someone other than the true household head can claim ownership of a few cows. The provision also allows brothers, or a father and his adult sons, to farm together without some having to be deemed homemen of another of them, in effect recognising the possibility of householder (bóndi) status of several adult males at the same farmstead ${ }^{27}$ and thus suggesting also the possibility of shared headship among such kinsmen. The sagas, however, offer little evidence of the merely juridical household whose 'householdness' is solely a function of the rules of thing attachment and their attendant property qualification. In other words, servants who have acquired property sufficient to make them bendr are not perceived as bendr nor as occupying a tvibyli at the farmstead where they are in service. We might need to be a bit less categorical to account for the situation of certain farm managers. One Mar Hallvardsson, for example, moved to his brother's son Snorri's farm with a lot of livestock (mart búfe) and took over the management of Snorri's household. Mar surely must have qualified as a bondi yet the saga is clear that there is but one household and it is Snorri's. ${ }^{28}$

There are other laws that point to the existence of complex households, although here too it is not altogether clear whether the provisions refer to more than one discrete household at the same location or to complex households. We find, for instance in a section devoted to eligibility for service on a panel of neighbours, that 'if two men live together in one house, it is right to call them both if needed, but only the one who is nearer if both aren't needed' (Grágás Ia 160). ${ }^{29}$ Another codex clarifies what it means to live nearer in the context of killing cases: 'He lives nearer to the place of action if he lives in that part of the house which faces in that direction' (Grágás II 376). Archaeological evidence shows that by the 
twelfth century the settlement period hall house had developed the amenity of a living area in addition to the hall and several other specialised rooms, and literary evidence confirms the existence of separate guest quarters, ${ }^{30}$ but there is nothing that indicates separate living quarters for different households at the same farmhouse. ${ }^{31}$ The reference to living in a part of a house may be to the location of a bed-closet, chest, or seat on the long benches running the length of the hall or perhaps to more than one free-standing living space at the same farm. Or the reference may be one of a number of places in the law texts where juristic hypercategorisation was more a function of the aesthetics of legal thinking and writing than of social reality.

But it is not possible to show conclusively that the 'juridical household' had no function outside of the narrow administrative purpose of regulating matters of thing attachment, although for the most part it seems that the juridical unit was functionally unimportant when compared to the coresidential unit. Still, the laws suggest a multiplicity of possible householding arrangements. Succeeding clauses in the section dealing with the eligibility of neighbours to serve on a panel tell how to proceed when people have a $b u$ together and one is a landowner and one is a tenant, when both are landowners, or when both are tenants (Grágás I a 160) ${ }^{32}$ Although bu is both the singular and plural form in the nominative and accusative cases, two appearances of búe as the singular dative object of a preposition in the passage indicate $b u$ is singular. If these provisions were dealing with discrete households at the same farmstead we might find the plural.

The sagas do not give us much detail about the day-to-day management of farms whose residents included more than one person who qualified as a juridical householder. But the glimpses we get suggest that they were run as a unified enterprise with divisions of labour along agreed lines, not as discrete entities with each qualifying bóndi hiring his own servants and arranging to pasture his animals separately. ${ }^{33}$ Even the instances of tvibyli do not show separate management. What we know for certain is that in the context of the feud the other side made no such fine distinctions between multiple discrete juridical households and true complex households. Anyone attached to the farmstead of an opponent, as well as kin and affines independently established elsewhere, were fair game; this despite a law that purported to limit the class of possible expiators when men householded together, by providing for a means of giving notice to the opposing group of one's refusal to be identified with the actions of the other householder. ${ }^{34}$ The same lack of concern with the category of the juridical household is also reflected in the attribution of names to groups. Group names are frequently taken from farm names or occasionally larger 
geographic units in which the chief residence is located (e.g. Haukdœlir, Austfirðingar). The names reflect a passive grouping imposed by outsiders and may include people unattached to the central household, but bound by kinship, affinity, or political ties to it (e.g. Ljósvetningar, Oddaverjar, etc.). ${ }^{35}$ Kinship also figured just as prominently in pan-household group names. A group of brothers could be collectively identified by their patronym (Sigfussynir, Sturlusynir), while wider kin groupings take the ing, ung patronymic with the first element taken from a prominent ancestor (Sturlungar, Ásbirningar). One interesting hybrid - Veisusynir ${ }^{36}$ - combines a farm name and a kinship term to describe second cousins who were fostered together by a common kinsman at a farm named Veisa. As the name Veisusynir suggests, coresidence was what in people's mind constituted the primary bond linking the fosterbrothers, so much so that the household bringing them together becomes, symbolically, their mother. Evidence like this suggests that, to outsiders at least, the farmstead was the crucial entity and whether some residents had sufficient property to make them boendr was only important if such a resident actually shared headship of the economic unit.

Shared headship was in fact not uncommon. ${ }^{37}$ It appears to have been the norm when brothers shared a joint household. When the extension was vertical, that is when father and son shared a farm, headship normally was the father's until he retired and formally handed the management over to his son. ${ }^{38}$ Still, there are subtle indications of shared headship even between fathers and sons. In Njáls saga, ${ }^{39}$ for instance, a man named Atli who is looking for a position intends to "meet with Njal and Skarphedinn to find out if they will take me in'. The outsider, Atli, evidently considers the son (Skarphedinn) to have equal say with the father (Njal) in matters of offering lodging to strangers. The answer Atli receives from Bergthora, Njal's wife, should further indicate some of the difficulty of speaking of sole headship in Iceland: 'I am Njal's wife ... and I have no less power to hire servants than he does.' Women too, both Bergthora and the laws ${ }^{40}$ remind us, could head households. In some cases it appears that a man who married a woman householder might find himself sharing headship with her. The evidence is thin but such an arrangement might be indicated by a brief notice where a person is said to be a landseti (tenant) of Snorri and Hallveig. ${ }^{41}$

\section{HOUSEHOLD MAKE-UP}

A farmhouse, then, generally had at least one householder, either male or female, but it could have more than one. Households also had, of course, dependants - children, of which more later, and the aged. Households 
with sufficient means could have occasional winter lodgers, usually Norwegian seamen, but also other transients who might be visiting by formal invitation or claiming shelter by right, as part of a general obligation of bandr to house people travelling to the things and bearing bodies to burial, ${ }^{42}$ or to lodge traders and wedding guests unable to complete their travels in accordance with rules regulating Sabbath observance (Grágás Ia 8, 24, 27).

\section{SER VANTS}

Everyone not him or herself a householder had to be attached formally to a household. Men over sixteen and single women over twenty were allowed to make their own lodging arrangements; others had them made by the person responsible for them (Grágás Ia 129). ${ }^{43}$ The arrangement was a matter of contract, with uniform, year-long terms beginning and ending during the Fardagar, Moving Days, in late May, during which new arrangements were made for the coming year (Grágás Ia 128-29). ${ }^{44}$ Almost all households mentioned in the sagas had some servants. Even the poorest of them had a serving woman or two who did the milking. ${ }^{45}$ The laws, however, in several places indicate the possibility of servantless households. The situation is unique enough that the head of such a household merited a descriptive term of his own and special attention in matters of being called to serve on a panel of neighbours. He was called an einvirki, 'sole-worker', and was eligible for panel service if he had twice the value of a cow for each member of his household (Grágás Ia 127-28, 159-60, II 320-21). An einvirki lost that designation as soon as he had a male servant at least twelve years old. Apparently an einvirki could have female servants and still be an einvirki. This provision adds to the plausibility of the saga evidence in which the poorest households have only women servants. Presumably many tenant bondr were einvirki, but the sources give us virtually no information regarding their householding arrangements.

Of special significance is the fact that the laws assume that servants could be married, with spouses located on the same farm or on another; this is confirmed by scattered saga evidence as well. ${ }^{46}$ Marriage, in other words, need not always depend on coming into an estate. Married servants with their dependants could be lodged together in the same household (see Grágás I a 131-2). A certain Thorstein, for example, lived with his children and his mother in the household of Hneitir for whom he worked and 'and was repaid well for his labor'. ${ }^{47}$ But the laws give the impression that servant families were often split up, with members parcelled out among a variety of households. This is the darker sense of 
the provision, noted above, that required a person to find places for all his dependants. ${ }^{48}$ Servants were not absolved of responsibility for their dependent kin, but in fact, their limited circumstances must have absolved them nevertheless. One brief notice in the laws intimates that the prospect of a servant's dependants showing up was of more than passing concern to the householder (Grágás II 147). If dependants of his servants or tenants appeared and these servants or tenants had not the means to sustain them, the householder was to call a meeting of the hrepp, the unit charged with overseeing the maintenance of the poor in their area (Grágás III 624). ${ }^{49}$

The ranks of servants were comprised of people of greatly different expectations. Sturlunga saga on occasion shows the sons of bandr as homemen in other boendr's households, that is as life-cycle servants, biding time until their fathers died or decided to share or cede authority in the management of the farm. Women, too, apparently could be life-cycle servants although the evidence is thin indeed ${ }^{50} \mathrm{We}$ are given a glimpse of the degree of independence such people had in the households to which they were attached in a brief account in Guomundar saga dýra where Solvi Thoroddsson, described as a housecarl of the Thordarsons, refuses to join the Thordarsons in an attack on their enemy. ${ }^{51}$ Some housecarls were able to acquire enough to buy farms and establish themselves independently. ${ }^{52}$ But the lot of a large number must have been permanent household service.

Occasional evidence in the sagas ${ }^{53}$ and reasonable inferences in the laws $^{54}$ suggest that a good portion of the permanent servants were poor relatives whose position in the household was a function both of the requirement of finding household attachment and of the obligations of kinsmen of sufficient means to bear responsibility for the maintenance of their poor kin. Such people must have had dim prospects of marrying. In any event the laws tried to discourage them by stipulating a minimum property requirement for marriage or cohabitation unless the women were incapable of bearing children (Grágás Ib 38-39, II 167). Violations were punished with banishment. The provision is difficult to assess. Although it evidences a clear interest in controlling the fertility of the poor, there is no way of determining its effect on nuptiality or fertility. The provision goes on to cast an especially wide net, suggesting that violations were frequent and that enforcement was problematic. Thus, the man who acted as the woman's fastnandi, i.e. the one who gave her in betrothal, was subject to lesser outlawry - i.e. three years exile and loss of property unless he had sufficient means to support the children. And he was to take them in himself; they were not to be foisted off on his kin. In some cases even the person who housed the wedding feast was subject to the same 
liability. The sagas show no prosecutions for violating the ban; they also show, as mentioned above, servants married or in fertile concubinage, but not with sufficient frequency to give any secure sense of the prevalence of marriage among servants of small expectations. ${ }^{55}$

\section{FOSTERING OF CHILDREN}

The young sons of bandr were frequently sent out for fostering, so frequently that several sagas think it noteworthy to record that someone 'was raised at home'. ${ }^{56}$ There were several types of fostering arrangements. In one type, supported by several well-known saga examples, foster parents were of lower status than the child givers ${ }^{57}$ and there is more than a suggestion that the foisting of children on lesser households was a mulct the big made upon the little. ${ }^{58}$ In another type, people, often kinsmen by blood or marriage, of fairly equal rank also figure as fosterers. The motivating force of this kind of arrangement might be to heal breaches in relations, as a way of confirming and buttressing arbitrated settlements. ${ }^{59}$ But fostering may also have been undertaken as a way of equalising the distribution of children among households. We do not see the sagas explicitly explaining fostering in terms of making up for short term demographic dislocations. But factors of this kind might well have influenced the type of bond that was used to establish cross-cutting ties between groups wishing to forge links between themselves. Whether such bonds would be created by marriage, say, or fosterage, had to be sensitive to the availability on one side, respectively, of marriageable women or children, and on the other side, of a need for wives or of space for children. This need not be an either/or proposition. Both marriage and fostering bonds were arranged at the same time. Thus when Njal marries his son to Asgrim Ellida-Grimsson's daughter, he also takes home Asgrim's son to foster. Later events suggest that this fostering was undertaken to provide Asgrim's precocious young son with legal training. ${ }^{60}$ Not surprisingly, the reasons behind any particular fostering were often multiplex. Considerations of support and money were supplemented by concerns for education and training ${ }^{61}$ or simply by desires to preserve peace within the household, as in those instances where fathers sent away young unruly sons. ${ }^{2}{ }^{2}$

Kin figure prominently as fosterers in another context. The obligation, mentioned above, of kin to maintain their poorer relations meant that a significant number of children grew up in the households of their better established kin. Such a situation could lead to a series of household attachments for those poor children who were 'fortunate' enough to have a clan of kin equally obliged to care for them (Grágás II 107-08). 
According to the laws all fostering of whatever type had to be paid for, either by paying the fosterer directly or by giving him support and protection (Grágás II 133-34, 136-38). It was thus provided that the relative, or the heir of the relative, who bore cost of maintenance of a poor child or kinsman could recover against the child the outlay (fóstrlaun) if the child came into any property (Grágás II 136-38). This was obviously not the kind of structural situation in which the quid pro quo for raising a child would be paid by support given to the child receiver by the child giver. ${ }^{63}$

Not all fostering relations meant the child was sent to another household. The same words were used to describe the intra-household relation of children of both sexes to their nurses and or to a male servant to whom much of their rearing was entrusted. ${ }^{64}$ In the case of little girls, the sagas give us few instances of a bóndi's young daughter being sent out for fostering. ${ }^{65}$ What little attention the sagas devote to young girls shows them growing up on their parents' farms, although again evidence of more widespread fostering is suggested in one saga where it was thought worth noting that two girls 'grew up at home'. ${ }^{6}$ Young women appear as lifecycle servants, ${ }^{67}$ and an occasional glimpse in a saga confirms what the laws suggest: that the realities of poverty meant that many young children of both sexes did not grow up in their parental homes. The evidence is patchy indeed, but what there is is consistent in suggesting a remarkable amount of circulation of children, either by virtue of formally concluded fosterage or by virtue of the consequences of impoverishment.

The sources are especially recalcitrant about household size. To credit the numbers given in the sagas, the size of the larger and wealthier households was substantial. Njáls saga says Njal had nearly thirty ablebodied men, to say nothing of women and children. ${ }^{68}$ Thorodd, a wealthy farmer in Eyrbyggia saga, had thirty servants (hjun) ${ }^{69}$ and Gudmund the Powerful, it is said, had a hundred servants and a hundred cows. ${ }^{70}$ This would make it comparable to the size of the bishop's household at Skalaholt which had 'seventy or eighty servants' ${ }^{71} \mathrm{Njal}$ 's household is the most well-known joint household of the sagas. In addition to $\mathrm{Njal}$ and his wife, three sons and a daughter with their spouses live in and share in the administration of the household. ${ }^{72}$ Thorodd's household type is complicated by the fact that he has taken in and maintains an old neighbouring couple who have retired from their farm. ${ }^{73}$ Only Gudmund and the bishop appear to have a 'simple' household, although Gudmund seems to have at least one married servant there who probably qualified as a bóndi. ${ }^{74}$

It is the larger and wealthier households of the chieftains and big farmers that generally capture the saga writers' interest. But there is enough light in the sources to see that tenants, some widows, and middling 
bændr must have had very small set ups. Thorkel Hake, a chieftain's son no less and by some accounts himself a chieftain, had a household peopled by his wife, a four-year-old daughter, a few women servants, one housecarl and one lodger. ${ }^{75}$ His poor household is cause for insults directed his way in another saga. ${ }^{76}$ There was also a poor bóndi named Amundi 'loaded with children', killed mowing hay, while his wife raked behind him with a child she was still nursing strapped to her back. There seems to have also been one woman servant in the household, but she was evidently not a wet nurse. ${ }^{77}$ Other modestly populated households elicited complaints from teenage sons and daughters about how boring they were. ${ }^{78}$ The evidence is such that any guess as to average household size would have no claim even to being 'educated'.

\section{RESIDENCE AT MARRIAGE}

Although the sagas often show new simple households being established at marriage, mostly among the wealthier families, neolocality was hardly a rule in a prescriptive sense, and the tendency admits so much exception as barely to be a rule in the descriptive sense. ${ }^{79}$ This is necessarily so when we recall the possibility of servant marriage. I have only been able to discover two normative statements regarding preferability of household type. Not surprisingly they cut in quite different directions. One appears to favour neolocality: hús skal hjóna fa $^{80}$ - 'a house shall have a married couple' - although the sentiment is also consistent with complex households, for example, by having a room or building at the parental farm. The other, whose context we will discuss later, favours complex households: 'It's best for the property of brothers to be seen together. ${ }^{91}$

The degree of actualisation of neolocality would depend, among other things, on the strength of the preference; it would also be sensitive to the demographic characteristics of the population. Assuming a roughly constant stock of working farms, a declining population in the twelfth and thirteenth centuries would facilitate neolocality; a rising one, if we assume no change in the age at marriage, would mean that a number of conjugal units would not have farms available to them at the outset of their marriages and that some units might never be able to establish themselves in a simple household either in a new location or on the parental farm. Our knowledge of marriage ages for men and women is too fragmentary to discern trends or even to determine a fixed point. What information there is suggests that marriage ages for those women who did marry was low. ${ }^{82}$ But even in a stable and stationary population, where a pool of farms might well be available to newly married couples, the realisation of neolocality would still depend on the existence of an active land 
market, ${ }^{83}$ and although there is plenty of evidence that farms were bought and sold during this period, the evidence also suggests that these transfers provoked disputes; bargaining was never quite free of duress and intimidation. The market, in other words, if market there was, was subject to the inefficiencies imposed by the pre-market mentalities of the people operating in it. ${ }^{84}$ But the near perfect darkness engulfing Icelandic demography gives us no basis for preferring one trend to another. ${ }^{85}$ Hypotheses and assumptions remain just that. We know that the number of boendr wealthy enough to pay the pingfararkaup was declining, ${ }^{86}$ but this tells us nothing about the population as a whole, nor does it allow us to make any special assumptions about household type. Tenants and poor farmers, after all, formed households too and their ranks might have been growing. ${ }^{87}$

There is another factor which suggests that even if neolocality was aspired to, it would not always be easy to achieve. There is reason to believe that the amount of land available for exploitation was shrinking in this period. ${ }^{88}$ Farms established at altitudes too high for economic exploitation in the settlement period were abandoned and acreage was wasted by volcanic eruption. The mayhem the settlers and their sheep committed on the environment took its toll. ${ }^{89}$ Soil erosion was assisted by the destruction of woodland and the cutting of turf for roofing and fuel. Furthermore, what productive land there was was already being exploited early in the eleventh century. New farms were not to be had by occupation of unexploited lands and there is no overwhelming evidence that heirs divided working farms into smaller parcels when dividing inheritances. ${ }^{90}$ Neolocality would thus appear to be a prerogative of the wealthy who could acquire extant farms by purchase, or, all too often, by extortion. ${ }^{91}$ We thus find a certain Eyjolf buying up the expectations of parties to an inheritance dispute because 'he had two sons and wanted to get them an estate' ${ }^{92}$ A prevailing neolocal rule among the wealthy would reinforce the movement, already initiated by the church, toward the assimilation of smaller independent farmers into the households of chieftains and big farmers, either as servants or as tenants maintaining households on smaller holdings. Scholars who have studied the matter have identified such a movement, although none have considered any of the impetus to be a consequence of marriage customs among the wealthier strata of the society. ${ }^{93}$

The sagas are explicit in revealing a multiplicity of possibility with regard to residence at marriage, which should make us wary of talking in terms of residence rules at all. Sons could take over their parents' households upon marriage by a kind of pre-mortem inheritance, with the parents staying on in retirement, ${ }^{94}$ or sons could stay on and farm jointly 
with their parents. ${ }^{95}$ Even married daughters might remain home with their husbands coming to join them..$^{96}$ Sons could also be established independently prior to marriage, at least among the chieftains' families, often with a concubine or kinswoman to assist running the household.$^{97}$ Those neolocal simple households once established tended to extend laterally quite quickly as brothers went to live, or sought refuge, with their married sisters or brothers. ${ }^{98}$

\section{THE PREVALENCE OF COMPLEX HOUSEHOLDS}

Several factors promoted the formation of complex households. Inheritance rules provided that legitimate sons took equally, and at the parent's death brothers might continue running the parental farm together rather than dividing the property.$^{99}$ There are many instances in the sources of brothers living together, presumably householding jointly. ${ }^{100}$ And households might be shared by father and married sons, brothers and sister's husband, father and daughter's husband, and even a man and his wife's brother and his wife. ${ }^{101}$ The whole politics of marriage arrangements assumed that a man stayed close (affectively if not always geographically) to his married kinswomen, just as it was expected that his wife was to stay close to her kinsmen. The husbands of daughters and sisters, and the brothers and father of one's wife, figured prominently in providing support in feud and lawsuits. ${ }^{102}$ When times were rough they were usually looked to for shelter and lodging. It was not at all unusual to find affines as household members; in other words, kinsmen of either spouse were eligible for household membership.

The demands of feud could lead households to merge formally for reasons of defence and protection. Thus, at Sturla's suggestion the household at Budardale combined with his in a félagsbú, i.e. a joint household. ${ }^{103}$ These same reasons appear to motivate the relatively shortterm joint householding arrangements entered into by Sturla Sighvatsson with his first cousin, and by his father Sighvat a generation earlier with his maternal aunt and her husband. ${ }^{104}$ Household mergers motivated by defence or protection were, it seems, seldom an affair of equals. Except in the cases of people like Sighvat and Sturla, it is hard to imagine that such arrangements ever led to shared headship. Protégés were often constrained to purchase protection either by assigning their property to the protector or by entering into service in the protector's household. ${ }^{105}$ Even though the laws stipulated the contract was to be a fair one and gave a cause of action to the heirs or ward to set aside any wrongful transfer, the sagas show very few successful reclamations by the heirs. ${ }^{106}$ But the assignor's farm would continue as a productive unit. It could become the endowment 
of a new household for the protector's kin, ${ }^{107}$ be managed by overseers, let to tenants, or be run by the assignor himself with aid from his patron, ${ }^{108}$ or even by the assignor's wife. ${ }^{109}$

One nearly obvious observation requires brief comment. Households broke up and were assimilated into wealthier ones because of poverty. A man and wife (hjun) were obliged to support each other unless the property of the provider (the laws explicitly make no differentiation on the basis of sex in this matter) dwindled to less than a year's sustenance for their hereditable dependants (Grágás II 141). In that case the destitute spouse was to return to his or her kin for maintenance. The households of the wider kin group, as noted earlier, were responsible for their destitute members as long as they had the means; if not, the poor became a charge on the hrepp (Grágás I b 3-4, 25-28). Another rule inimical to household survival required a person to go into debt slavery in order to maintain mother (in all cases), father (in some cases) and children, who according to one provision could themselves be sold into debt slavery instead (Grágás Ib 4-6). One Grágás provision enabled the poor householder saddled with dependants to leave his household to work for wages and also permitted his children similarly to hire themselves out for the summer (Grágás II 266). These kinds of employment meant, invariably, that people went to live where they found work. Icelandic poor law is too complicated to go into here in any detail but it confirms the fragility of households living on or below subsistence levels; it also suggests and helps to explain why we might expect to find a wide range of kinsmen, who were detached from their own 'nuclear' units, resident in the houses of their better established relatives. ${ }^{110}$ Wealth and the complexity of household type were highly correlated.

Evidence like this should make us wary of looking for and finding simple households inhabited by nuclear families in early Iceland. The evidence, such as it is, shows how varied householding arrangements could be, how unconstrained by rule, how open to formulation by agreement of the parties. The sources could also be culled for a multitude of instances relating to simple households and neolocal marriage. But many of these simple households are captured by the source at a particular phase, a phase prior to household break-up, if the family was impoverished, or a phase prior to complex householding, if the unit was wealthy. Still, our evidence does not allow any way of determining how many joint and other complex householding arrangements there were as a percentage of how many there could have been, given the constraints imposed, or the situations rendered possible by mortality, nuptiality, fertility, the strength of cultured preferences, land markets, and the carrying capacity of the land. And our inability to determine prevalence 
severely undermines any attempt to determine the significance of the examples we have found. My suspicion is that joint households were significant, and complex households of all types almost assuredly were, because the reasons for the existence of complex households are ones that were directly related to factors - inheritance practices, demands of feud, land shortage, legal stricture - that were fairly constant throughout the twelfth and thirteenth centuries. The ease with which examples of complex householding can be culled from the sagas is all the more remarkable given that presumably high mortality rates must have both severely reduced the number of families where shared householding might even have been demographically possible, and also substantially reduced the amount of time a household could have had a complex phase for those families where complex householding was demographically possible. ${ }^{111}$ Noteworthy too is the fact that the sources register utterly no sense of unusualness when complex households are present. The significant presence of complex householding is all the more remarkable considering that these households existed in the face of laws facilitating their dissolution. The laws do not speak directly about partition of joint households, but they have much to say about concurrently owned property. Although nowhere explicitly stated as a general rule, there was a right to partition almost all property jointly held. Sections of Grágás detail the procedures for partition of jointly owned land along with the buildings and water supply, of woods, and of fishing rights in a stream, and carefully regulate the limits of use of jointly owned pasture ( $\mathrm{I} b \mathrm{86}-90$; $108-12 ; 122-23 ; 113-16)$. As long as the petitioner owned a share of the property, there was no defence to a partition action. There was thus no legal way to keep jointly owned property from passing into single ownership at one person's will, while nothing, except the coincident circumstances of death and a class of heirs greater than one, could force individually owned property into joint property. The legal deck was stacked in favour of individual ownership. ${ }^{112}$

The sagas, so rich in detail about feud between households, and about strife and feud between kin residing in different households, are rather impoverished in accounts of fission of joint and complex households. We have some cases, which I will turn to shortly, but they are not graced with the dense web of circumstance typical of saga accounts. There are several possible reasons, not entirely consistent, for the relative silence. The simplest, and most unsatisfying, is that saga subject matter tends to be tales of feud, that is, of inter-household disputes. The literary form focussed on extra-household affairs, and only in the fuller accounts do we get more than an occasional detail of internal household politics. There are also indications that break-ups were relatively peaceful and hence 
unlikely to merit a detailed account. Certain factors stifled internal strife before it was actualised. If the joint arrangement were of the kind suggested by the laws, e.g. where one householder was the landowner, another the tenant, or where one was the protector and the other the protégé, that is, when we have several juridical households at the same farmstead, one party was usually so much the weaker that his opportunities for articulating grievance beyond a mumble here and grumble there might be limited. Joint or extended households of the type where father and son shared authority were more likely to be divided by death than dispute, even though the sagas do not hesitate to show sons at odds with their fathers or fathers jealous of their sons. ${ }^{113}$ Mortality rates would also be responsible for ending many frèreches before friction did the same.

We know from the sagas that shared ownership of property by people of different households was fertile ground for dispute, leading to some of the best known feuds in the sagas; ${ }^{114}$ the paucity of similar descriptions regarding disputes between joint householders may indicate the effectiveness of certain countervailing forces that kept these arrangements from causing serious dispute. The norms against kinstrife might not prevent kin from having, and articulating, antithetical interests once independently established, ${ }^{115}$ but these norms appeared to have been honoured when kin lived together, at least to the extent that disputes within the household did not end in violence but in avoidance. ${ }^{116}$ It may be that many of the brief notices that so-and-so went abroad are, in fact, recording a resolution of intra-household discord. If brothers did not get along they often knew this before their father died and did not embark on joint householding. In such cases the separation of brothers would take place at predictable times which were already liminal periods where transition and transformation surprised no one. A situation which could have led to a break-up of a joint household was prevented by an uncontentious succession. Or, even if the succession were contentious, it was perceived and processed as an inheritance dispute and not as one having its origins in a particular type of household. ${ }^{11 ?}$

Although the sources are at best indirect about this, the structure of both internal and external household politics, as much as norms of peacefulness, gave rise to forces that promoted cooperation between joint heads. The demands of defence in the feud, the identity of interest imposed by opponents and competitors, served to unite the farmstead membership against the outside world. But these same forces could lead to the articulation of competing positions within the household. Cooperation between joint heads was assisted by a fairly predictable resistance endured at the hands of their charges. The more disenfranchised household 
members had their own district and neighbourhood agendas; their status depended on how the wives, sons, ageing parents and servants at other households perceived them and their household, and how opinion and gossip determined their relative standing. The manner in which they acquired and maintained status often opposed them to their own household head whose dealings with other household heads required different strategies. ${ }^{118}$ Numerous cases in the sagas show wives, mothers, old fathers, and even servants urging and sometimes compelling the household head to a more violent course of action than he desired. ${ }^{119}$ These internal stresses are well documented, but we lack detailed accounts of their effect on joint households; conjecture must, unfortunately, suffice. There was never, however, a very clear demarcation in Iceland between inter and intra, public and private spheres, although as a rough division it still reflected a real difference between the directedness of the roles assumed by heads as opposed to that of their charges. Internal household politics were greatly complicated by competing loyalties occasioned by kinship, affinity, fosterage, and friendship of individual household members with different households. Whatever forces of adhesion household politics might engender between joint heads could be quickly offset by the consequences of bonds each might have to different outsiders. And when that occurred, as we shall see in the second case below, any consequent household fission, because more 'public', would have a better chance of becoming the subject of a saga account.

\section{SAGA CASES}

Some sense of the factors leading to the formation and dissolution of complex households can be acquired by considering more closely two of the relevant saga cases. This brief account is from Ljósvetninga saga:

Gudmund's property passed to his sons Eyjolf and Kodran. Eyjolf wanted to have the inheritance all to himself and had no wish to deal even-handedly with his brother... When Kodran came of age he asked Eyjolf for a division of the property to which Eyjolf answered, 'I don't want a joint household (tviby'li) at Modruvellir and I don't want to move on your account.'

Then Kodran met with his foster father, Henni, and told him how things stood: 'Is there no valid defense if I'm going to be robbed of my inheritance?'

'Eyjolf's arrogance comes as no surprise to me,' replied Hlenni, 'and I do not advise you to forfeit your inheritance. You should rather build a house outside the enclosure at Modruvellir.'

He took that advice and it was agreed later that Kodran should live at Modruvellir (12:61-62).

We do not know the marital status of the brothers; we do know that Eyjolf was not always the most fairminded of men. But guardians often 
come to see their wards' property as their own and there is something rather predictable, if not altogether admirable, in Eyjolf's highhandedness. ${ }^{120}$ His reluctance to have a tviby'li is doubtless attributable to having grown accustomed to the 'simple' household in which he was the head. ${ }^{121}$ The conclusion of the dispute, apparently establishing the tvibyli that Eyjolf had resisted, suggests that the dispute would not have arisen had Kodran been of majority when Gudmund died. The indication is that the brothers would simply have lived together - "it was agreed later that Kodran should live at Modruvellir'. ${ }^{122}$ There is no evidence here of strong norms against brothers staying on together on the paternal farm. On the contrary, Hlenni's advice involves a symbolic statement of Kodran's right to be part of the household at Modruvellir in equal standing with Eyjolf. Kodran is to build a hús, not establish a bu, right under his brother's nose, a building which, though an outbuilding, is still a part of Modruvellir, which Kodran still claims is at least half his bu. The plan is designed to annoy Eyjolf and to embarrass him in the eyes of the community by providing a vivid emblem of his lack of good kinship. At the same time, Kodran avoids the unseemliness and dim prospect of suing his brother or engaging in violent self-help. To be noted also is Eyjolf's precise response to his brother's request for a fjárskipti, a property division. Eyjolf does not take this to mean that Kodran wishes to move out, but construes it as a request to set up a joint household, although with individual ownership of personal property (i.e. a tvibýli). This is a small but significant indication that property division upon inheritance did not necessarily mean physical partition. The household remained thus constituted until Kodran was killed years later.

The second case involves the division of a frèreche. After the death of Thorbjorn, his two sons, Thorkel and Gisli, marry and continue to farm together. Their sister Thordis marries a short time later receiving the entire farmstead as her dowry. ${ }^{123}$ Her husband Thorgrim relocates there, while the brothers obtain a farm and set up household on neighbouring land. Thorkel comes to suspect his wife of having an affair with Gisli's best friend, who is also the brother of Gisli's wife, Aud, and at the next Moving Days Thorkel approaches Gisli to request a division of their property:

'I want us to divide our property. I want to move and join householding with Thorgrim, my brother-in-law.'

Gisli responded, 'It's best for the property of brothers to be seen together. I would surely prefer there to be no disruption and no division.'

'We can't continue to have a household together (eiga builag saman), said Thorkel, 'because it's a great wrong that you always do all the work by yourself and have all the care of the household and I do nothing useful.'

'Don't make anything of it,' said Gisli, 'as long as I haven't mentioned it ; we've managed when we got along and when we haven't.' 


\section{HOUSEHOLDING IN THE ICELANDIC COMMONWEALTH}

'It doesn't matter what is said about it,' said Thorkel, 'the property has to be divided; and because I'm the one requesting the division, you shall have our residence and land and I shall have the personalty.'

'If there's no other way than for us to separate, then do either one or the other, divide or choose, because I don't care which of the two I do.'

It was concluded that Gisli make the division; Thorkel chose the moveables and Gisli had the land. They also divided the dependants, two children; the boy was named Geirmund and the girl, Gudrid; she stayed with Gisli, Geirmund went with Thorkel (10:34-35). ${ }^{124}$

At the time of their parents' deaths the brothers were of age. And unlike the preceding case, there being no conflicting interest between guardian and fraternal ward, the brothers established a joint household on the parental farm. The arrangement was resilient enough to survive transfer of the farm to their sister and the building of a new farmstead nearby. The timing of joint household fission in this case had nothing to do with the major transitions in a household's lifecycle. Death, marriage, birth, or retirement were not at issue. We know the brothers did not get along all that well. One would expect the difference in the amount of labour contributed by each to have been a source of contention. But neither that, nor other difficulties in the past, if we credit Gisli - 'we've managed when we got along and when we haven't' - had been sufficient to sunder the household before. ${ }^{125}$ It seems that up until now Thorkel had neither felt enterprising enough to set up independently, nor had he had a convenient opportunity to set up common householding with someone else. But the establishment of his sister next door provided such an opportunity and the new knowledge that his wife was involved with the brother of Gisli's wife provides the pretext for taking advantage of the opportunity.

If we abstract from Thorkel's actions a general principle about household fission it would involve the impingement of extra-household attachments and bonds on intra-household politics. Both brothers had extra-household attachments to people that the other brother was hostile to and, in this case, each brother favoured his non-resident friend. As long as the household was only one of several non-congruent solidarities claiming effort and commitment from a person, householding arrangements would be subject to the state of affairs in the other groupings. It is clear that Thorkel's wish to break off householding with Gisli had nothing to do with his feelings toward joint householding per se. He just preferred sharing a residence with his sister and her husband to sharing with his brother and his wife. The property division caused no net loss of joint households to the society. Thorkel's new arrangement, however, was shortlived, not because of conflict within his new household, but because of mortality rates, this time arising from the person of Gisli, who killed his sister's husband a year later $(16: 53)$.

The lot of the two dependants calls for comment. In accounting terms 
and according to Grágás they are liabilities and subject therefore to division (see, e.g. Ib 5). They were brother and sister and very possibly kin to Gisli, although the saga is unclear about this. ${ }^{126}$ The history of their household attachments reveals much about the fluidity and instability of residence in early Iceland for all but those who headed households. ${ }^{127}$ They were born in one place, raised together in another, presumably because of the poverty of their parents, and then separated from each other when the joint household broke up. The sources, both legal and narrative, are consistent in giving the impression of constant circulation, of children especially but of servants too, from household to household, either by way of fostering, poor relief, employment or other lodging agreements. ${ }^{128}$ Discussions of household types and the family relations accompanying them, unless set forth with life-course diagrams, tend commonly to give a misleading sense of stasis and of order. In Iceland people moved a lot. They circulated to compensate for localised demographic dislocations. To ameliorate localised shortfalls in production, occasioned either by production failures or fertility successes, people moved to food, food did not move to people. ${ }^{129}$ And in this case people moved because of discord, something the nature of the saga sources would have us believe was, next to marriage, the most prevalent cause of relocation.

What must Geirmund and Gudrid have thought about all this? The saga tells us that Geirmund remained loyal to both Gisli and Thorkel. Elsewhere in the sagas, household attachments of even brief duration give rise to future claims of support, mostly in matters of feud and dispute. ${ }^{130}$ For the non-householding class, the possibility of changes in residence needed to be faced annually during Moving Days. For those who were the sons of householders, the residential life course was likely to have been only a little less volatile: reared for a time in parental and a time in fostering households, a homeman in another's household, a juridical joint householder still largely subject to the power of his better propertied fellow householder, or perhaps independently established by his father. He might share household authority with his father, or set up joint householding with brothers at the father's death or divide the inheritance and set up a simple household.

A daughter of the householding class would probably be reared at home, but could be sent out at an early age for service, then remove to husband's or lover's residence, unless she was an heiress or widow in which case the man could relocate to her lands. ${ }^{131}$ In marriage her residence would be that of her husband unless they divorced, or in concubinage until her consort married or they separated. If widowed she might return to her kin, ${ }^{132}$ or if propertied, remarry and relocate. ${ }^{133}$ For 
the daughters of the wealthiest, the cycle was similar except they were unlikely to be sent out for service and somewhat less likely to be involved in concubinage.

Few could escape obligation towards or claims by several different households. Although one was legally a resident at only one place per year, there are suggestions that this was, at best, a juridical ideal not confirmed by a reluctant reality. Some people were in fact attached to more than one householding unit. Take, for instance, Hoskuld, Njal's illegitimate son who was part of his father's household but who frequently stayed at his mother's farm nearby. Simultaneous or shifting membership in two households must have been fairly common for illegitimates, of which, according to genealogy and saga, there were a multitude. ${ }^{134}$ On the other hand, the numerous brutal provisions in the laws regarding the gangamenn and lausamenn ${ }^{135}$ those unattached to any household, serve as a reminder of the economic limitations that made householders unable to absorb all those who were available for service. Thus the words of one Helgi Sealball: 'I never have a home; I never have the fortune to have a year's lodging. But I'm always hired on for wages in the summer. '136

This brief introduction to a complicated subject, further complicated by the nature of the sources, is provisional at best. Future study of medieval Icelandic householding needs better demographic information than woefully inadequate conjectures based on intuitively derived household multipliers. ${ }^{137}$ From the late seventeenth and early eighteenth century there is a complete census (1703), ${ }^{138}$ land registers and parish registers. But considering the near perfect darkness of the preceding centuries it will not be possible to fashion serviceable back projections to the thirteenth century, even though the demography of Iceland in 1703 was produced by the population of the thirteenth century with little assistance or detraction from immigration or emigration.

What I have tried to show here is that without the means, as yet, of determining prevalance or significance, it is impossible to declare, as Jochens does, ${ }^{139}$ the nuclear family and the simple household to be the dominant type. In fact, the evidence such as it is suggests the contrary. There was no unambivalent systemic pressure toward the formation of simple households. Complex householding, we saw, was discussed in the laws and confirmed by the sagas with such frequency that attempts to push the north-west European household pattern as far north and as far west as Iceland and as far back as its twelfth and thirteenth centuries cannot be supported by the evidence. The shrinking availability of land, the pastoral transhumance directed from large lowland farms, the demands of defence in the bloodfeud, limited evidence of partitible inheritance of working farms, were all factors that presumably were 
relatively constant throughout the twelfth and thirteenth centuries. None of these factors was especially conducive to the formation and maintenance of simple households. The orthodox terminology - simple, multiple, joint, complex - while useful for comparative purposes, ultimately misrepresents the richness of possibility in the constitution and interrelations of the population of an Icelandic farmstead.

Some final formulaic reservations are in order. The fact of the wide circulation of people between households, the various status of those recruited - kin, affines, workmen, lodgers, feuding allies, fosterees - the legal and moral obligations to care for kin and the poor of the district, all these factors mean that an accurate depiction of Icelandic householding should be accompanied with full accounts of practical kinship and practical inter-household relations. I plead as my excuse the conventions of length and the conventions of topic definition in article format, not a lack of awareness of the interconnections.

Old Icelandic names have been Anglicised in the usual manner: th for thorn, $d$ for eth, unligatured vowels for their ligatured counterpart and omission of diacritics. Old Icelandic technical terms, however, appear unaltered as do bibliographical entries and the names of modern Icelandic scholars. All translations of the sagas are my own. This paper was presented in earlier drafts at colloquia at Stanford and University of Iowa. Thanks are owing to the participants in the colloquia and to Kathleen Koehler.

\section{ENDNOTES}

1 See, e.g. Carl I. Hammer, 'Family and familia in early-medieval Bavaria', in Richard Wall, Jean Robin and Peter Laslett, eds., Family forms in historic Europe (Cambridge, 1983) $217-48$, at 243-6 ('the distribution of household types seems to provide striking confirmation from the early ninth century of early-modern family history: the simple or nuclear family was the overwhelmingly dominant type'); cf. however, David Herlihy, Medieval households (Cambridge, MA, 1985) 70-2, who finds evidence of pronounced lateral extension on the estates of St Germain-des-Prés in the early ninth century. See, e.g. Carl N. Degler, At odds: women and the family in America from the Revolution to the present (Oxford, 1980) 8-9 ("the modern American family emerged first in the years between the American Revolution and about 1830'). See also the discussion in Jack Goody, The development of the family and marriage in Europe (Cambridge, 1983) 24-6. Whatever the strength of the arguments may be, there is, one feels, some ideological tendentiousness not far below the surface of many works that discover ever-earlier declines of collectivities and risings of utility maximising individuals nurtured in simple households. A new romanticism of the simple household appears to have replaced an older romanticism of cooperating collectivities.

2 Jenny M. Jochens, 'En Islande médiévale: A la recherche de la famille nucléaire', Annales ESC 1 (1985) 95-112 at 106.

$3 \mathrm{Ibid}$. 100, 105-7 and see below, n. 82. Assuming a stationary or expanding population, an early age of marriage for both sexes would make it more difficult for new conjugal units to have their own farms and would tend toward the creation of complex households than would a later age of marriage.

4 See, generally, J. Hajnal, 'European marriage patterns in perspective', in D. V. Glass 
and D. E. C. Eversley, eds., Population in history: essays in historical demography (London, 1965). The difficulty of determining marriage age, among other things, even with much better evidence than is available in Iceland, is exemplified in the spirited debate between Zvi Razi and his critics regarding methods of interpretation of manorial court records in English local studies. The possibility of relatively late age for England has been argued by R. M. Smith, 'Some reflections on the evidence for the origins of the "European marriage pattern" in England', in C. Harris, ed., Sociology of the family: new directions for Britain, Sociological Review Monograph, 28 (Keele, 1979) 74-112, and controverted by the evidence in Razi, Life, marriage, and death in a medieval parish: economy, society, and demography in Halesowen 1270-1400 (Cambridge, 1980). Razi's methods are criticised in L. R. Poos and R. M. Smith, " "Legal windows onto historical populations?" recent research on demography and the Manor Court in medieval England,' Law and History Review 2 (1984) 128-52. Response and counter response have followed: see Razi, 'The use of manorial-court rolls in demographic analysis: a reconsideration', Law and History Review 3 (1985) 191-200; Poos and Smith, " Shades still on the window": a reply to Zvi Razi,' ibid. 409-29; and Razi, 'The demographic transparency of manorial-court roles,' Law and History Review 5, (1987) 523-36.

5 See, e.g. 'the critiques and attempts at resolution', in Sylvia J. Yanagisako, 'Family and household: the analysis of domestic groups', Annual Review of Anthropology 8 (1979) 161-205; Michel Verdon, 'Shaking off the domestic yoke, or the sociological significance of residence', Comparative Studies in Society and History 22 (1980) 109-32; Robert McC. Netting, Richard R. Wilk, and Eric J. Arnould, 'Introduction', in Netting, Wilk, Arnould, eds., Households: comparative and historical studies of the domestic group (Berkeley, 1984) xiii-xxxviii; Wilk and Netting, 'Households: changing forms and functions', ibid. 1-28; E. A. Hammel, 'On the *** of studying household form and function,' ibid. 29-43; Richard Wall, 'Introduction', in Family forms in historic Europe, 1-65; J. Hajnal, 'Two kinds of pre-industrial household formation systems', ibid. 65-104; and Peter Laslett, 'Family and household as work group and kin group: areas of traditional Europe compared', ibid. 513-63.

6 See, e.g. Hajnal, 'Two kinds of pre-industrial household formation systems', 99-100, who requires the assignment of everyone uniquely to one household and also presupposes only one head per household.

7 Verdon's formulation in 'Shaking off the domestic yoke', and adopted by Laslett in 'Family and household', 515, takes coresidence as the defining characteristic of the domestic group. Hajnal, 'Two kinds of pre-industrial household formation systems', 99, defines household as the housekeeping or consumption unit and requires eating together or 'sharing of meals derived from a common stock of food'.

8 See Wall, 'Introduction', in Family Forms, 35.

9 See Peter Laslett and Richard Wall, eds., Household and family in past time (Cambridge, 1972) 28-31 ; and Wall, 'Introduction', Family Forms, 19.

10 'Joint' in Hajnal, 'Two kinds of pre-industrial household formation systems', 68-9, $77-8$, corresponds for the most part to Laslett's 'multiple' in Household and family, 28-31. A 'multiple' household requires two or more conjugal units which in most instances will be married couples but might also be a widow and her children. I make no arguments that depend on the distinction being maintained.

11 Bonds based on concubinage, like those founded on marriage, were invoked in gathering support for feud. See, e.g. Njáls saga $98: 251-52$, Íslenzk fornrit 12 and also Gudmunder saga dýra St. I: 15:192, where A asks B to support him in a lawsuit because, says the saga, two of B's children were by A's sister. The family sagas are cited by chapter and page number in Íslenzk fornrit (Reykjavik, 1933-), hereafter IF. The 
chapter divisions in these editions are maintained in most accessible English translations of the sagas. I supply the IF volume number for the first citation of a saga or paitr (short saga). Sagas in the Sturlunga compilation are sigilled by St. before volume, chapter and page in Jón Jóhannesson, Magnús Finnbogason, and Kristján Eldjárn, eds., Sturlunga saga (Reykyavik, 1946).

12 I am extending the household to include what Lasiett and Wall call the houseful; that is, all those residents who are not spouse, child, relative, or servant of the household head (Wall, Family forms, 35; e.g. Lutz K. Berkner, 'The use and misuse of census data for the historical analysis of family structure', Journal of Interdisciplinary History 4 (1975) 721-38; Our information is seldom circumstantial enough to know whether residents who are not children are kin to the head or not. We simply do not know whether servants who could claim some kind of kinship with the householder were more privileged than servants who could not.

13 Even the best of sources have their problems. It is well-known that census data might under-represent the significance of joint householding. Berkner, 'Use and misuse', 726; also Robert Wheaton, 'Family and kinship in Western Europe: the problem of the joint family household', ibid. 601-28, at 606-9.

14 The laws are preserved in two main manuscripts. They are known by convention as Grágás and date mostly from the twelfth and thirteenth centuries. The surviving manuscripts are not official compilations. They are remarkable for the detail of their provisions and the sheer number of them. For example, the court procedure section alone numbers more than one hundred pages in the standard edition, the rules and procedures governing rights in land another seventy. In contrast to the barbarian codes, the difficulties interpreting Grágás tend not to involve frustrating ellipsis and terseness, but rather the usual problem of how to assess the connection between legal norms and social practice. The mass of detail does create its own problems. Internal inconsistencies suggest that Grágás preserves some obsolete provisions. But there is no reason to doubt that most of the provisions were in effect some time within the twelfth and thirteenth centuries. Citations of Grágás are to the volume and page number of the editions of Vilhjálmur Finsen: Grágás: Islandernes lovbog i fristatens tid, udgivet efter det kongelige bibliotheks haandskrift (Copenhagen, 1852), hereafter Grágás Ia and Ib; Grágás efter det Arnamagnaanske haandskrift 334 fol., Stadarhólsbók (Copenhagen, 1879) hereafter Grágás II; and Grágás, Stykker som findes i det Arnamagnaanske haandskrift 351 fol. Skálholtsbók (Copenhagen, 1883), hereafter Grágás uI. All three volumes were reprinted in 1974 by Odense Universitetsforlag. Sections 1-116 of Grágás I a have recently been translated in Andrew Dennis, Peter Foote, and Richard Perkins, Laws of early Iceland: Grágás (Winnipeg, 1980). There are also some sixty or so máldagi, i.e. charters, dating from the twelfth and thirteenth century, briefly evidencing gifts to the bishoprics; they are unfortunately of minimal value in this study.

15 See Grágás II 145-6; Njáls saga 142:386. For brief treatments see Jón Jóhannesson, $A$ history of the old Icelandic commonwealth, tr. H. Bessason (Winnipeg, 1974) 347-9. Our only evidence of the precariousness of the lot of the kotkarl or cotter must be extracted from a simile recording the reluctant parting of an old chieftain from his land: 'Glum sat in the high seat and did nothing to prepare for his departure, even though he was called. He had the hall decorated with tapestries; he did not want to depart his land like a kotkarl'; Viga-Glums saga $26: 89$, IF 9.

16 See above, n. 11.

17 Literary sources, in a way little different from law codes and custumals, raise problems of how accurately they reflect reality. To reject a source because it is literary is a luxury of those historians who have what, by the conventions of the trade, are assumed to be 
better sources, if for no reason other than that they are duller. The historian of medieval Iceland has no choice. But this is not as bleak as it sounds. The sagas, unlike romance and even most heroic fare, are consciously realistic. The narrator purports only to report the disputes of Icelandic farmers. The action, except for occasional trips to the continent, takes place in Iceland, in familiar countryside, in familiar interiors. There is simply no reason for the redactor to fashion the cultural and social setting of his story ex nihilo in order to tell his tale. Fictionalising dialogue, inventing characters, does not mean fictionalising the setting in which the action takes place. It does not even mean fictionalising the structures of possible action. In other writings I have made use of comparative materials, usually anthropological ones, to provide a sense of the limits of the possible in a stateless feuding society such as Iceland was. The sagas fall well within the range of described patterns in the ethnographic literature. They look credible in most matters and although some of that credibility might be the conscious creation of sophisticated writers, it is just as likely to be owing to accurate description. For more on the problems in saga scholarship regarding the historicity of the sagas see generally Carol J. Clover, 'Icelandic family sagas', in Clover and John Lindow, eds., Old Norse-Icelandic literature: a critical guide (Ithaca, 1985) 239-315; and also, Clover, 'Introduction,' to volume on 'Early law and society' in Scandinavian Studies $\mathbf{5 8}$ (1986) 97-100.

18 The deteriorating climate was aided by the ineptitude of the native response to resource management; see Gísli Gunnarsson, 'A study of causal relations in climate and history with an emphasis on the Icelandic experience', Meddelande frän Ekonomisk-Historiska Institutionen 17 (Lund, 1980) and Thomas H. McGovern et al., 'Northern islands, human error, and environmental degradation: a view of social and ecological change in the medieval North Atlantic', unpublished MS presented at the 1985 American Anthropological Association Meeting, Washington, D.C.

19 See Jóhannesson, A history of the old Icelandic commonwealth, 303-05 and Gunnarsson, 'A study of causal relations', 14-23.

20 See R. Cleasby and G. Vigfusson, Wm. A. Craigie, ed., An Icelandic-English dictionary, 2nd ed. (Oxford, 1957) and Jan De Vries, Altnordisches Etymologisches Wörterbuch (Leiden, 1961).

21 See Eyrbyggja saga IF 4, 14: 24: 'I am not willing to divide Helgafell (the farmstead); but I can see we are not suited to have a tvibyli together so I wish to buy you out.'

22 See, e.g. n. 32 and accompanying text and compare text quoted at n. 123.

23 An earlier form, buandi, shows the clear link to bú. Bóndi is the present participle of buia, 'to have a household'.

24 The griomaör of the laws usually appears as a hískarl or heimamadr in the sagas. A heimamaðr need not imply low social rank; like gríomaðr it means someone formally lodged ( $a$ vist) in another's household. See, e.g. Thorvard, a chieftain, who is called a homeman (heimamaðr) of Kolbein; Íslendinga saga St. I: 177: 501.

25 The householder was thus obliged to attend the local thing, or send a proxy if he was not able to attend, to support his chieftain (OI godi, pl. godar). In fact the obligation meant much more than just attending the thing. Both thingmen and gotar looked to each other for support in feud as well as law and one's god $i$ was a nearly indispensable party to disputes with other householders. Thingmen were free to change chieftains upon formal announcement; Grágás Ia 140-41.

$26 \mathrm{By}$ 'the merely juridical household' I mean to indicate the theoretical household defined by minimal property requirements that give rise to the obligation to declare one's thing attachment as provided in the Grágás provision just cited in the text.

27 This also suggests that access to bondi status was not especially difficult to achieve and 
in no way depended on neolocal marriage. See text at n. 79 .

28 Eyrbyggja saga 15:26. This case is also indicative of the possible range of extension in some larger households.

29 Both men in this passage have to be bondr or the passage is without motivation, since in order for there to be a problem about whom to call both would have to be eligible to be called, i.e. bandr.

30 See the description of the farmhouse at Flugumyr where nine men suffocate in the gestahis which apparently was not detached from the main building (Íslendinga saga St. I: 173: 492) and cf. Hoskuld Hvitanessgodi's establishment at Ossaboer where he lodges guests in útibuir (outlying buildings) because his hall was being repaired (Njáls saga 109: 277). Bath-houses were often detached from the main dwelling; see Gísli Gestsson, 'Fjórar Baðstofur', in Guðni Kolbeinsson, ed., Minjar og Menntir : Afmalisrit helgađ Kristjáni Eldjárn, (Reykjavik, 1976) 190-207.

31 See, e.g. Kristján Eldjárn, 'Two medieval farm sites in Iceland and some remarks on tephrochronology', in Alan Small, ed., The fourth viking congress, 1961, (Edinburgh, 1963) 10-19; and Porkell Grimsson, 'Miðaldabyggð á Rayðarfelli', in Minjar og Menntir, 565-76.

32 'If two men have a household together and one of them is a landowner and the other a tenant, then the landowner is to be called. If two landowners have a household together or two tenants who can legally be called, then he shall call the one who owns the greatest portion of the household. But if they have equal shares in the household then he shall call whom he wishes from the two of them even though they have no servant. If two men have a household together who are obliged to pay the pingfarakaup [a tax to be paid by those thingmen who meet a certain property requirement in lieu of thing attendance to help defray costs of those who do attend] who do not have a servant it is legal to call one of them. The other shall then pay all the costs that are necessary in proportion to the share he has in the household.'

The same provision, several lines later, contemplates the presence of a married daughter and her husband living with her father: "For the household of a man incapable of attending the thing it is lawful to call the following four men if they have their residence there: i) the man's son, ii) his stepson, iii) the near affine who has married his daughter, and iv) his legal fosterson whom the householder has raised'.

33 See, e.g. Eyrbyggja saga 15: 26; Gísla saga IF 6, chs. 9-10; Guđmundar saga dýra St. I: 11: 181-82; Njáls saga 14:45-47.

34 Thus Grágás 1a 126 provides that if men live together [equally possible: household together] and one of them takes in an outlaw and the other does not want to, then the one who does not want to is to name witnesses that he does not want to and that it is without his agreement and say this to five of his neighbours after. Then he is not liable for living with an outlaw as long as he gives him no other aid'. A discussion of the difficulties of repudiating actions of a group of which one was arguably a member can be found in William Ian Miller, 'Justifying Skarpheðinn: of pretext and politics in the Icelandic bloodfeud', Scandinavian Studies 55 (1983) 316-44, at 328-32. For a general discussion of group liability and the class of expiators in the bloodfeud see Andreas Heusler, Das Strafrecht der Isländersagas (Leipzig, 1911) 57-9.

35 This statement is an impression derived from the sagas and undertaken without a formal study. Group names tend to be used by the narrator and characters who are not group members. This, however, does not prevent members of the group from adopting the name to reference themselves in opposition to others; see, e.g. Ljósvetninga saga IF 10, 23: 69: 'We Ljosvetnings know that your hostility to us has long been unsparing.'

36 Ljosvetninga saga 22: 64. 


\section{HOUSEHOLDING IN THE ICELANDIC COMMONWEALTH}

37 Hajnal's definition would require one head per household; see above n. 6 .

38 Egils saga 56: 151; Laxdoela saga 29: 49.

39 Njáls saga 36: 95.

40 See, e.g. Grágás, which provides rules for thing attachment where a bóndi marries a woman who has a bú (Ia 139); for men eligible to represent a household headed by a woman (Ia 161); governing the killing of foreigners who are lodged in her household (Ia 173; II 340) and the disposition of her property (I b 229). The sagas confirm the existence of such households, usually of widows, but unmarried heiresses also headed households; see, e.g. Njáls saga 18:52 (Unn); Guđmundar saga dýra St. I: 5: 168 (Gudrun Thordardottir). One more matter of brief note: Sturla Sighvatsson's household at Saudafell includes, among others, his wife and his wife's mother. Both are designated with the title huisfreyja (Íslendinga saga St. I: 71:327). Although the mother-in-law might simply bear the title as an honorific and a reflection of past status, this is not altogether clear. Could it be that his mother-in-law had sufficient wealth that she qualified as a head of a separate juridical household? For the possible connection between households headed by widows and witchcraft accusations see William Ian Miller, 'Dreams, prophecy and sorcery: blaming the secret offender in Medieval Iceland', Scandinavian Studies 58 (1986) 101-23, at 114-15.

41 Islendinga saga St. I: $69: 324$.

42 See also Eyrbyggja saga $51: 143-44$.

43 'If a man had not found a place for those people whom he is responsible for on the previous Moving Day he is to be fined for each of them and the action belongs to anyone who wishes to prosecute.'

44 See Jóhannesson, $A$ history of the old Icelandic commonwealth, 355-58.

45 See, e.g. Porsteins páttr stangarhøggs IF 11, p. 70 (household of Thorstein); Ljósvetninga saga 13: 16, 18: 51 (household of Thorkel Hake); Hrafns saga Sveinbjarnarsonar St. I: 17: 221 (household of Amundi),

46 Saga evidence suggests that many of these were loose marriages; see, e.g. Ljósvetninga saga 13: 16-17 (marriage); Hrafns saga Sveinbjarnarsonar St. I: 14: 218 (concubinage); Sturlu saga St. I: 4: 65 (concubinage); Njáls saga 39: 103 (concubinage); Reykdaela saga 30: 24 (marriage). One of Hajnal's essential features of north-west European household formation is the circulation of young people between households as servants before marriage; 'Two kinds of pre-industrial househoid formation systems', 92-9. Service of this sort, he observes, did not exist in joint household systems such as India. Some of the people in service in medieval Iceland were of the north-west European kind, but many did not appear to be. Servants were often poorer kin of the household head, and many seem to have formed a fairly permanent underclass. Although Iceland did not have a joint household system in the manner of India neither was it yet a society whose householding arrangements were typified by the north-west European model.

47 Dorgils saga ok Haflida St. I: 1: 12-13, 5: 17.

48 See above, n. 43. The laws contemplate separate households for a husband and wife who must find household attachment: "If a man has a wife, he shall have found her a position and informed her of it before the fifth day of the week when seven weeks of summer have passed at the latest. If a place has not been obtained for her, so far as she knows, then she has the right to find a position for herself where she wishes' (Grágás Ia 129). Likewise: 'If a servant marries and each has lodging in a different place, each shall remain where they are in service if they are bound by their work' (Ia 135). Marriage without coresidence is rare in Europe, if not always so in ethnographic literature; see Robert Wheaton, 'Observations on the development of kinship history, 1942-1985', Journal of Family History 12 (1987) 290. For the separation of a father and son see Íslendinga saga St. I : $141: 440$. 
49 On the hrepp see Konrad Mauer, Das Staatsrecht des isländischen Freistaates (Leipzig, 1909) 499-525; vol. 4 of Vorlesungen über Altnordische Rechtsgeschichte (1907-1910); also Jóhannesson, A history of the old Icelandic commonwealth, 86-9.

50 Life-cycle service appears to be what Isolf intended for his daughter in Ljósvetninga saga 22: 64 in sending her to Eyjolf, although some of these arrangements must have been scarcely distinguishable from concubinage; e.g. consider the succession of housekeepers that Thorgils skardi sought and retained (Borgils saga skarda St. II : 27: 151-52); see also Hávarðar saga Ísfirðings IF 6, 1:291.

51 Guömundar saga dýra St. I : 10: 179; see also Sturlu saga St. I : 20:89; and Dorsteins saga hvita IF 11, 3: 6. It is of some interest that Solvi is provided with a patronym. The sagas do not care to give us much detail about servants; they are frequently unnamed or if named they are often without patronymic, although in this matter Sturlunga saga is more likely to provide a patronym than the family sagas are. The presence of a patronym is likely to indicate a bóndi's son and thus, perhaps, a life-cycle servant. See, e.g. what appear to be life-cycle services in Sturlu saga St. I: 12: 78 (Hall?); 15: 72 (Thorolf); Vodu-Brands páttr IF 10, 2: 128-31 (Brand). Younger brothers and kinsman of the powerful Sturlungs could be homeman to their seniors; but there were short-term arrangements and although they might be called homemen they were unlikely to have been servants in any meaningful sense; Islendinga saga St. I: $81: 344$ (Kolbein and Orækja). Nevertheless Sturla Sighvatsson can at least contemplate reducing his kinsmen to service; ibid. $125: 407-8$.

52 Gunnars páttr Didrandabana IF 11, 1:196-7; Sturlu saga St. I: 2: 64; and 15:81.

53 E.g. Hrafnkels saga IF 11, 8: 126 (Eyvind's skósveinn, i.e. shoeboy, servant).

54 On the obligation to maintain poor kinsmen see generally Grágás, Ómaga-bálkr', Ib 3-28, II 103-51, esp. Ib 3-4, 11, 26-27.

55 Compare, however, the incredibly low nuptiality rates for Iceland in the census of 1703 , suggesting a virtual prohibition of servant marriage as claimed in Gisli Gunnarsson, 'Fertility and nuptiality in Iceland's demographic history', Meddelande frän Ekonomisk-Historiska Institutionen, Lunds Universitet, 12 (1980) 7-15 and questioned in Hajnal, 'European marriage patterns in perspective', 137-38.

A provision like this could not hope to achieveits goal unless there were also effective ways of discouraging illegitimacy. Strictures against fornication and seduction provided for a declining scale of punishment depending on the status of the woman involved. This would have the effect of insulating men of the householding class in their depredations on servant women while protecting their wives and daughters from poorer men (Grágás I b 48); but it would not do much to discourage illegitimacy. In any event lia bility for support attached to the father of the child or to his kin or the hrepp if he was unable to assume the obligation. For the manner in which the laws dealt with impoverished men who made it a habit of producing bastards, see below, n. 134.

56 Laxdela saga 28: 76; $74: 215$; Gisla saga 2: 7 (describing, however, events in Norway). Contrast with this the 1703 census which has $77.8 \%$ of children $0-14$ living at home; Gunnarsson, 'Fertility and nuptiality', 9.

57 Droplaugarsona saga IF 11, 5: 150; Hansa-Dóris saga IF 3, 2: 7; Laxdela saga 16: 37.

58 In addition to the cases in the preceding note see Sturlu saga St. I: 25: 98.

59 Laxdrela saga 27: 75; Njáls saga 94 : 237; Sturlu saga St. I: 34 : 113; Viga-Glúms saga 12: 40-41.

60 Njáls saga $27: 74$.

61 Prestssaga Guðmundar góda St. I: 4: 123.

62 Such may have been a contributing motive in the fosterings mentioned in Ljósvetninga saga 22: 63 and Viga-Glúms saga 17:57. 


\section{HOUSEHOLDING IN THE ICELANDIC COMMONWEALTH}

63 The sagas give us no examples of suing to recover the fóstrlaun and the accounts of kinsmen taking in the children of kin who have met untimely deaths or whose fathers have gone abroad do not indicate whether they were repaid; one case suggests that there was no intention that it should be repaid other than by support; Njáls saga $93: 236$. See also Laxdala saga 50: 158; Porsteins saga hvita 7:17. There is, however, an ironic use of fóstrlaun which might indicate otherwise. Thus after Bolli has killed Kjartan, Thorgerd, who is Kjartan's mother and Bolli's foster mother, thinks Bolli has 'made a sorry repayment for his fostering' (sár fóstrlaunin); Laxdcla saga 51 : 159.

64 E.g. Egils saga IF 2, 40: 101; Njáls saga 9: 29; 39: 103.

65 See Honsa-Fóris saga $11: 32$; Reykdoela saga $28: 238$. These are the only saga examples unless we also include the late Viglundar saga IF 14, 7:75.

66 Viga-Glums saga 10:36.

67 Ljósvetninga saga 13:16-17 (Gudrun); Njáls saga 39: 103 (Gudfinna).

68 Njáls saga 128: 325.

69 Eyrbyggja saga 54: 150; see also ibid. $11: 18$ (60 freemen).

70 Sorla páttr IF 10, 1: 109. The number of servants seems excessive, but given the number of servants the number of cows is not excessive. In this regard note that the minimal property requirement obliging a farmer to pay the pingfararkaup was a cow free of debt or the value of a cow for each of his skuldahjün; see the text above at nn. 20-21 and also Jóhannesson, $A$ history of the old Icelandic commonwealth, 289-90.

71 Páls saga byskups 5: 260 in vol. 1 of Byskupa sögur, Guðni Jónsson, ed. (Reykjavik, 1953).

72 Jochens, 'En Islande Médiévale', 107, would attribute this complex household to the dramatic purposes of an author who needed to have these people residing together so that they could be burned together as per the demands of the plot. Even if, admittedly, the extent and complexity of Njal's household are somewhat aberrational, the fact that it is extended or complex is not. Moreover, Islendinga saga St. I: 170-73: 481-92 indicates that a group of people who did not share a household could be conveniently burned together as invitees to a feast.

73 Eyrbyggia saga 50: 139.

74 Ljósvetninga saga 13: 16-17.

75 Ibid. 13: 16, 18: 51.

76 Njáls saga $120: 305$.

77 Hrafns saga Sveinbjarnarsonar St. I: 17: 221.

78 Hansa-Póris saga 16: 42; VQđu-Brands páttr 1: 125.

79 'Neolocalism', in the jargon of anthropology, refers to the practice of a newly married couple setting up on their own, and living by themselves, not with either set of parents; Laslett, 'Family and household', 531. A rule of neolocality implies, therefore, simple households.

80 Hungrvaka 1: 2 in Guð̃ni Jónsson, ed., Byskupa sögur 1 (Reykjavik, 1953); CleasbyVigfusson's gloss, s.v. hjün, I: 'a married couple should get a house' is less ambivalent but hard to justify grammatically.

81 Gisla saga 10: 34: 'Saman er brœðra eign bezt at líta ok at sjá.' See below text at nn. 123-29.

82 Jochens, 'En Islande Médiévale', 100, describes three marriage models typical of Sturlunga saga. In one, men are twenty and women eighteen or younger. In a second a young man marries an older woman, usually a widow with children. The third is the inverse of the second. The second and third type would do little to raise the average age of first marriages, assuming that the younger men who take older women then take younger women at a later stage of their life cycles. Jochens gives no numbers regarding 
the prevalence of the types, nor is there any way, given the nature of the evidence, that she could. We have no means of determining the number of celibates, nor the prevalence of illegitimacy in any quantifiable way. Jochens' models are taken from Sturlunga saga, a source perceptibly skewed to the wealthy and powerful families, and only for the most wealthy and powerful of these are the accounts sufficiently circumstantial to allow for even a moderately accurate determination of age. Nevertheless, it should also be noted that the laws envisage the possibility, at least, of very early marriages for women. Consider Grágás ia 224: 'If a women is married when she is sixteen or younger ..., 'If she is widowed when she is younger than sixteen ...' and such marriages are confirmed by the experiences of principal female characters in Laxdela saga 34: 93 and Njáls saga.

83 In a stationary population roughly $20 \%$ of all married couples will produce no children surviving their parents and another $20 \%$ will produce only daughters who survive their parents. See E. A. Wrigley, 'Fertility strategy for the individual and the group', in Charles Tilly, ed., Historical studies of changing fertility (Princeton, 1978) 135-54.

84 See William Ian Miller, 'Gift, sale, payment, raid: case studies in the negotiation and classification of exchange in medieval Iceland', Speculum 61 (1986) 18-50, at 49-50. A sale of land would most likely involve a loss of status for the seller, since straitened circumstances, fertility failure, or insufficient strength to stand up to the would-be purchaser would be the usual reasons the land would be available in the first place; see, e.g., Laxdœla saga 75: 218-21; Sturlu saga St. I: 15-16:81-84 (cases of Erlend prest and Ozur's inheritance); 23: 96.

85 Our information about medieval Icelandic demography is very limited; see Kirsten Hastrup, Culture and history in medieval Iceland (Oxford, 1985) 165-77.

86 lbid. 170.

87 Hastrup, 172-77, takes this view.

88 See, e.g. Jóhannesson, $A$ history of the old Icelandic commonwealth, 29-34, 345-50; Jesse L. Byock, Feud in the Icelandic saga (Berkeley, 1982) 143-50; Thomas H. McGovern et al., 'Northern islands, human error, and environmental degradation: a view of social and ecological change in the medieval North Atlantic'; Hastrup, Culture and history in medieval Iceland, 189-96.

89 S. Thorarinsson, 'Tephrochronology and Medieval Iceland', in Rainer Berger ed., Scientific methods in medieval archaeology (Berkeley, 1970) 295-328, at 320-5.

90 Hastrup, Culture and history in medieval Iceland, 172, deduces the partition of lands from the inheritance rules, but saga evidence suggests that this need not be the case; see below, n. 99.

91 The examples of neolocal marriage in Jochens, 'En Islande Médiévale', 98-101, involve only the wealthiest chieftain families.

92 Gudmundar saga dýra St. I: $1: 162$. There is no indication of the marital status of the sons, but it should be noted that Eyjolf apparently intended them to have one establishment together.

93 See the references above, n. 88.

94 Sturlu saga St. I: 7: 69; Gudmundar saga dýra St. I: 1 : 161 ; but cf. Egils saga 79: 275.

95 Egils saga 56:151. The son could have equal say in the running of the household even though he was unmarried; see Laxdala saga 20:49.

96 Laxdoela saga 35: 96-7; 43: 130; Njáls saga 61 : 154; 90 : 225; Sturlu saga 25:97. See also the Grágás provision quoted in n. 32.

97 Laxdoela saga 20:49; Íslendinga saga St. I : 39: 284; 86-7: 358-60; see also Jochens, 'En Islande Médiévale', 97, 101.

98 See, e.g. Gisla saga $10: 34$; Ílendinga saga St. I: $4: 232 ; 33: 262 ; 81: 344 ; 83: 346-7$; Sturlu saga St. I: $9: 72$. Although it is of little probative value for the medieval period 
the presence of the householder's siblings was a marked feature of households enumerated in the 1703 census, marked, that is, relative to roughly contemporaneous figures for England, Geneva, and Norway; see Manntalid 1703, table VIII, and Wall, 'Introduction', in Family forms 53.

99 Grágás Ia 218; Gísla saga 4: 16; Ljósvetninga saga 22: 62; Sturlu saga St. I: $3: 65$ (although brothers mismanage their affairs and must sell land shortly thereafter). Brothers could also formally divide the inheritance. Still, as far as I know, there is only one partition in kind of a family farm at the death of a parent when the decedent's sons were the heirs; Valla-Ljóts saga $3: 241$. Among the wealthier families who might control more than one farm, property divisions among brothers at the death of a parent tended to keep farms intact; Hrafnkels saga 10: 133; Njáls saga 78: 192. A practice noted in the family sagas has one brother take his share in livestock, the other his share in land; Laxdoela saga 26: 73; Gisla saga 10:35. Partitions of lands were more likely when the class of heirs included people not related to each other; Viga-Glums saga 5: 15; see also Eyrbyggja saga 14: 24-25.

100 The marital status of the brothers is not always determinable; but see, e.g. Gisla saga 4: 16; Guðmundar saga dýra St. I: 11: 181; Heiđarviga saga IF 3, 41:326; Islendinga saga St. I: 46: 294; Laxdola saga 32:86; 46: 144; Ljósvetninga saga 20: 54; 22:62; Njáls saga 47: 120; Sturlu saga St. I: 3: 65; Porgils saga skarða 14: 123.

101 Íslendinga saga $\mathrm{St}$. I: 86: 358 (Br \& SiHu), 33: 262 (WiBrs); Laxdela saga 46: 139 (Fa \& So); Egils saga 56:151 (Fa \& So); Laxdela saga 32: 86 (Br \& SiHu); Njáls saga 61: 154 (DaHu); Sturlu saga St. I: 7: 69 (Fa \& So, WiBr, WiBrWi), 25: 97 (DaHu).

102 Affinal relations, especially those with sisters' husbands and daughters' husbands, tended to be kept in good order. The laws recognise the closeness of these kin (Grágás Ia $47,62,201$ ) and the sagas confirm them as particularly active in matters of vengeance; see, e.g. the roles of Kari in Njáls saga, Thorgrim alikarl in Guðmundar saga dyra; Otrygg in Ljósvetninga saga 24: 77.

103 Sturlu saga St. I: $15: 82,19: 87$.

104 Íslendinga saga St. I: $106: 383$ and 32: 260.

105 Sturlu saga St. I: 28: 103; Dorsteins dáttr stangarhoggs, 77-8.

106 See Grágás Ia 246-9, II 85-7 (setting aside transfers of ancestor); Ib 76-7, 410-14 (setting aside transfers of guardian); see also $\mathrm{Ib}$ 17-18. Successful reclamations were usually made in blood rather than at law; Eyrbyggja saga 32-7: 87-102; Hávarðar saga Ísfiroings 14: 337-41.

107 E.g. the estate of Thord Goddi in Laxdorla saga 16:37; 22:62 and Reykjaholt in Íslendinga saga $\mathrm{St}$. I: 16: 241.

108 E.g. Eyrbyggia saga $31: 84$.

109 Sturlu saga St. I: 28: 103.

110 See, generally, 'Ómaga-bálkr', Grágás Ib 3-28, il 103-51.

111 Wheaton, 'Family and kinship in Western Europe', 611 .

112 The notion of individually owned property must be qualified to some extent to take account of the claims of heirs and dependants. I do not wish to enter here into the mostly arid debates about the rise of individualism. I mean only to indicate that it is the difference in the way in which title to a particular piece of property is conceived that determines whether all of it or only some fraction will be subject to the owner's direction or be considered an asset of his estate when he dies.

113 See, e.g. Bandamanna saga IF 7, 1 : 294; Egils saga 40: 102; 58: 173; Eyrbyggja saga 30: $81 \mathrm{ff}$; Laxdxela saga 24: 66 where it is noted that Olaf's father did not envy his son's popularity, implying the likelihood of the contrary.

114 Eyrbyggja saga 30:82-3 (jointly owned field); Njáls saga 36:92 (jointly owned woods). 
115 See, e.g. Eyrbyggja saga 30: 81ff; Laxdoela saga (Bolli v. Kjartan); Ljósvetninga saga $2-4: 6-15$; and generally the dealings of the Sturlusons in Islendinga saga. Inheritance disputes, almost by definition, frequently pit household members against each other.

116 It may be of some interest that the sagas record no patricides, filicides, or fratricides, although there are some very close calls. See, e.g. Ljósvetninga saga 20: 57 where a father must be restrained from torching a house in which he knows his son is lodged, after the son has refused an offer of free passage; also ibid. 2: 9; similarly Porgils saga skarda St. II : $32: 160$ although this time it is the son who is willing to burn his father. We might grant one case of filicide if we are to count sins of omission. Thorkel, a priest, prefers to confess his son and hand him over to his executioners rather than pay them the compensation they request; ibid. $30: 158$.

117 E.g. Hrafns saga Sveinbjarnarsonar 8: 285-86 in Gudbrand Vigfusson, ed., Sturlunga saga, vol. II (Oxford, 1878); Ljósvetninga saga 21: 61-62.

118 The dispute between the households of Gunnar and Njal in Njáls saga is perhaps the best example; see also Porsteins páttr stangarhoggs. It is in this context that the goading women and old men of the sagas should be understood for which see my 'Choosing the avenger: some aspects of the bloodfeud in medieval Iceland and England', Law and History Review 1 (1983), 159-204.

119 An occasional notice in the sagas suggests that disputes between homeman and householder need not remain repressed. A certain Grim is given an end consonant with his name in this brief notice: 'he was killed by his housecarls'; Porgils saga ok Hafliða St. I: $11: 30$.

120 See, e.g. Eyrbyggja saga 14:24-6; Laxdola saga 19:45-7; but cf. Hrafns saga Sveinbjarnarson St. I: 13:214; Sturlu saga St. I : $26: 100$. The property of minors (below sixteen for males, twenty for females) was administered by a guardian called the fjárvaroveizlumadr. In the absence of a father the role would be filled by a brother who had reached majority; see Grágás Ia 225-6.

121 A similar case occurs in Eyrbyggja saga 14:24-6 where Snorri claims his paternal inheritance from his stepfather who, though willing to pay out the inheritance is not willing to share a houschold: 'I am not willing to partition Helgafell', he said, 'but I see that we are not suited to have a joint household ( $t$ iby $i l i)$ together, so I will buy you out.'

122 The passage could be more tendentiously but properly rendered: "it was agreed later that Kodran should have a household at (bjo i) Modruvellir'. See Cleasby-Vigfusson, s.v. buia A.I.4.

123 Gisla saga 5: 19.

124 Geirmund and Gudrid are siblings, very possibly kin to Gisli, who are in service with Gisli and Thorkel. The value of Gisla saga's evidence for householding should perhaps be discounted somewhat because the householding type figures more integrally in the plot than the general run of saga householding evidence and hence is more likely to suffer fictionalising distortions. That said, there is nothing in the description of householding arrangements in the saga that is inconsistent with the accounts derived from safer contexts.

125 Gisli, for example, had killed Thorkel's best friend in Norway before they emigrated. The two brothers were frequently at odds over controlling sexual access to their sister Thordis. For the dependants see text below at note 126 .

126 See Gísla saga, xiv.

127 Some notice should be made here of demand divorce. According to the sagas, in preChristian times either husband or wife could renounce the marriage simply by doing so in the presence of witnesses. After the introduction of Christianity, separation ostensibly required the bishop's approval except in the following cases: if the couple 
were unable to support their dependants, if one dealt the other an injury or wound, or if one spouse had wealth and the other did not and the latter's dependent kin were a drain on the property of the other (Grágás Ib 39-40). Sturlunga saga indicates that separation was not uncommon; see, e.g. Islendinga saga St. I: $3: 231 ; 53: 304 ; 75: 335$; 82: 346 .

128 See above, text and notes at nn. 56-63.

129 See Miller, 'Gift, sale, payment, raid'.

130 E.g. Vodu-Brands páttr 2: 130-31.

131 Instances of uxorilocal marriage were not uncommon; sec, e.g. Laxdoela saga 35: 96-7; 43: 130; 69: 203;70:207-08; Gudmundar saga dýra St. I: 5: 169; 12:186. Couples could also relocate to provide care for ageing parents; see, e.g. Laxdola saga 10: 20.

132 Gudmundar saga dýra St. I: 1. 162; Viga-Glúms saga 11:40.

133 See the second marriage of Gudrun in Laxdela saga and Hallgerd's second and third marriages in Njáls saga. Wealthy widows had a hard time staying unattached and often entered into, or were constrained to enter into, joint householding arrangements or loose marriages with men intent on their property; e.g. Sturlu saga St. I: 2: 64; Islendinga saga St. I: 52: 302.

134 Gunnarsson, 'Fertility and nuptiality', 15-9, doubts excessive illegitimacy. As has become the frequent refrain in this paper, we just do not know. If we count the children of concubines as illegitimate then the sagas and genealogies suggest the rate was quite high among chieftains. The people most concerned with keeping the rates low were those upon whom the burden of support ultimately rested, that is kinsmen or members of the hrepp. Thus Grágás Ib 26: 'No one is obliged to accept more than two illegitimate third cousins fathered by one man unless the father of the children is castrated', and further ( $\mathrm{Ib} 28$ ) where it is provided that the kin of vagabonds were not liable for their children unless the parents attached themselves to a household.

135 The provisions are brutally unsympathetic. Besides being liable for full outlawry (Grágás Ia 139-40) vagrants and those who showed them charity were subject to a number of legal disabilities. E.g. fornication with a beggarwoman was unactionable ( $\mathrm{Ib} 48$ ); it was lawful to castrate a vagabond and it was unactionable if he were injured or killed in the process ( $\mathrm{I}$ b 103); one could take in beggars only to whip them ( $\mathrm{Ib}$ 179); nor was one to feed or shelter them at the thing on pain of lesser outlawry; their booths could be knocked down and if they happened to have any property with them it could be taken from them without liability (I b 14).

136 Fóstbroðra saga IF 6, 14: 195.

137 See above, n. 85.

138 Statistical Bureau of Iceland, Manntalid 1703 (Reykjavik, 1960); Björn Larusson, The Old Icelandic Land Registers (Lund, 1967).

139 Jochens, 'En Islande médiévale'. 